\title{
NEW MODELS FOR PRODUCT PLANNING
}

\author{
S. Konstantinova* \\ Faculty of Economics, University of Food Technologies - Plovdiv, Bulgaria
}

\begin{abstract}
The purpose of the present study is to develop the methodology of business planning through the establishment of new models for the formation of the product plan of a company. A set of methods such as strategic analysis and synthesis, differentiation method, grouping method, matrix planning method, graphic methods, etc. are used. The results of the study have enabled two models to be developed with the purpose to improve the product planning. The first model involves product allocation depending on their importance for the economy and the development of the company. The second model, created on the basis of the methodology of the Boston Consulting Group, presents the technology for determination of the level of significance of each product. The application of the new product planning models into the practice of the company improves the economic results and adds new value to the corporate valuation.
\end{abstract}

Key words: planning, model, product, matrix

\section{INTRODUCTION}

The effectiveness of marketing is of fundamental importance to the economy of industrial companies. Product planning is a key component of marketing that greatly determines its effectiveness. It needs to be continuously enriched with useful tools, including new models and metrics for product planning.

I propose the following conceptual model for the formation of the product plan. All products and services produced by the company are divided into the following three groups:

I group: Strategically significant products - those that provide a fairly high contribution to the company.

II group: Tactically significant products - those that provide a good profit for the company.

III group: Operationally significant products - those that provide a significant turnover (revenue) for the company in the current period and in the near future.

\section{MODELS, RESULTS AND DISCUSSION}

The ranking criteria (the rating is perceived as part of scalar quality assessments. Ratings

*Correspondence to: Assoc. Prof. Snezhinka Konstantinova Stoyanova, PhD, Faculty of Economics, University of Food Technologies Plovdiv, Bulgaria, Cell Phone: +359 878384372 , E-mail: sks_ko@abv.bg themselves have no value outside the context of their reference scale) of the products in the company nomenclature are determined as follows:

- Contribution to the company (Price Direct costs);

- Profit for the company (Revenue - Costs);

- Revenue (turnover) for the company (Price).

This grading of the importance of the individual products and services makes it possible to plan appropriate marketing goals and apply appropriate marketing strategies to each individual group and even product. In this respect, it is appropriate to use the following matrix in the formation of the product plan Table 1.

The presented product grading (ranking) enables the managers to provide the best possible marketing support for the Group I products during the formation and implementation of the business plan. Additionally, the company's entire investment policy can be readjusted to a more accelerated incorporation in the production capacity of the products from this list. Certainly, the grading criteria adopted should not be absolutized, because a marketing goal could also be to gain a larger market share through the Group III products. 
Table 1. Matrix model of the product plan

\begin{tabular}{|c|c|c|c|c|}
\hline $\begin{array}{l}\text { Groups } \\
\text { Products }\end{array}$ & $\begin{array}{l}\text { Marketing } \\
\text { goal }\end{array}$ & $\begin{array}{l}\text { Marketing } \\
\text { strategy }\end{array}$ & $\begin{array}{l}\text { Necessary } \\
\text { investments }\end{array}$ & $\begin{array}{c}\text { Term of } \\
\text { incorporation into } \\
\text { the product list }\end{array}$ \\
\hline $\begin{array}{l}\text { I. Strategically significant: } \\
\text { 1. Product } 1.1 \\
\text { 2. Product } 1.2\end{array}$ & & & & \\
\hline $\begin{array}{l}\text { II. Tactically significant: } \\
\text { 1. Product } 2.1 \\
\text { 2. Product } 2.2 \\
\end{array}$ & $\begin{array}{l} \\
\ldots \\
\ldots \ldots \ldots \ldots \ldots \ldots \ldots \ldots\end{array}$ & … & $\begin{array}{l}\ldots \ldots \ldots \ldots \ldots \ldots \\
\ldots \ldots \ldots \ldots \ldots \ldots\end{array}$ & $\begin{array}{l}\ldots \ldots \ldots \ldots \ldots \\
\ldots \ldots \ldots \ldots \ldots \ldots\end{array}$ \\
\hline $\begin{array}{l}\text { III. Operationally significant: } \\
\text { 1. Product } 3.1 \\
\text { 2. Product } 3.2\end{array}$ & - & & & $\ldots$ \\
\hline
\end{tabular}

In order to effectively link the product and the investment plans, I suggest transformation of the "growth-share" matrix of the Boston Consulting Group (BCG) into another model. As it is known, the "growth-share" matrix is the most popular metric developed and used by the global company BCG. It is applied to the strategic planning for products, projects, etc. By using the two-dimensional space with four quadrants, I offer a new model for strategic planning.

In the BCG model the market growth represents the potential for revenue growth and the relative market share - the competitive strength of the company. Relative market share means the proportion of the company's sales in comparison to the leading competitor.

The sectors of the Bulgarian economy are dominated by small and medium-sized enterprises. In fact, managers and specialists working therein have hardly any data on market shares that are already difficult to identify and find. Therefore, by using the BCG methodology I offer a new model "Contribution to growth", which has the following form Figure 1:

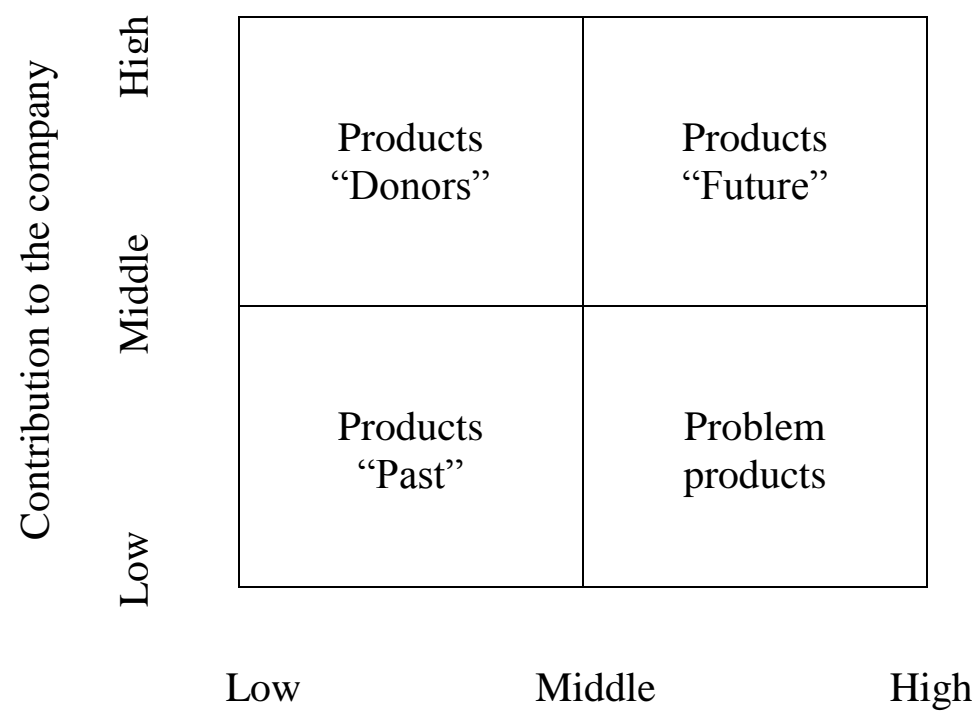

Market growth rate

Figure 1. Contribution to growth matrix model.

The practical formation of the matrix by managers and professionals of small and medium-sized enterprises is relatively easy and convenient:

- the contribution is determined by deducting the direct costs that are easy to find from the price. The indirect costs for depreciation, organization and management, lighting and heating, and so on, have always been the difficult ones. Particularly difficult from a methodological and practical point of view is the distribution of these costs, which are the total amount between the individual products, and the determination of the cost price and hence - their profit and profitability; 
- the market growth is also relatively easy for managers and professionals by comparing the sales from past periods with the sales during the current period.

According to the Contribution to Growth matrix, the company's products can be ranked in the following way in the company's product plan (1):

I group: Products "Future" - strategically significant products.

They bring not only high returns but also their sales are growing. The plans should provide for dominant investment and marketing support for this product group that forms the promising business.

II group: Products "Donors" - tactically significant products.

They also bring high returns, but their market share is relatively low. Their investment and marketing support differs:

- their marketing support should be good enough to improve the company's financial position and economic potential;

- in terms of investment, they can be supported with short-term investments, but long-term investments are not recommended.

III group: Problem products - tactically significant products.

This product group is characterized by a relatively low profitability, but its market potential is growing. Their planning should also be differentiated:

- in the marketing plan provision should be made for moderate support measures;

- resources and actions should be included in the investment plan with the purpose to increase the contribution by reduction in costs, improvement of quality and hence of the price, etc.

Investments in this product group are considered to be risky. Managers should carefully monitor the development of the group III products because:

- some of them will move to the most promising product group, especially as prices rise due to the growing demand. This transition will also occur upon appropriate investments therein;

- others will go into the group of products that need to be removed from the product list or of products the production of which will be maintained by necessity.

IV group: Products "Past" - operationally significant products.

This product group has a relatively low contribution and low market potential. It is inappropriate to plan marketing and investment events for their support. Managers should divide the products from this group into two subgroups:

I subgroup - products that should be produced and offered by necessity; for example, with the purpose of meeting the needs of strategic customers, maintaining a wide assortment, production of products promoters of other products, etc.

II subgroup - products that should be removed from the product list.

The methodology on which the "Contribution to growth" matrix is based enables the managers to compile a more robust and workable product plan using the following table form:

Table 2. New matrix model of the product plan (under the "Contribution to growth" matrix)

\begin{tabular}{|l|c|c|c|c|}
\hline \multicolumn{1}{|c|}{$\begin{array}{c}\text { Groups } \\
\text { Products }\end{array}$} & $\begin{array}{c}\text { Contribution } \\
\text { per unit }\end{array}$ & $\begin{array}{c}\text { Market } \\
\text { growth }\end{array}$ & $\begin{array}{c}\text { Marketing } \\
\text { budget }\end{array}$ & $\begin{array}{c}\text { Investment } \\
\text { budget } \\
\text { (thousand BGN) }\end{array}$ \\
\hline $\begin{array}{l}\text { I. Products of perspective } \\
\text { business: }\end{array}$ & & & & \\
1. Product 1.1 & 0,38 & 23,16 & 12,30 & 45,00 \\
2. Product 1.2 & 0,41 & 19,21 & 7,20 & 11,60 \\
\hline $\begin{array}{l}\text { II. Products of profitable } \\
\text { business: }\end{array}$ & & & & \\
1. Product 2.1 & 0,43 & 6,40 & 8,50 & 4,45 \\
2. Product 2.2 & 0,36 & 1,14 & 1,20 & - \\
\hline III. Products of risky business: & & & & 5,21 \\
1. Product 3.1 & 0,06 & 14,43 & 0,60 & - \\
2. Product 3.2 & 0,01 & 16,82 & - & - \\
\hline IV. Products of fading business: & & & & - \\
1. Product 4.1 & 0,03 & $-6,23$ & - & - \\
2. Product 4.2 & 0,04 & $-10,21$ & - & \\
\hline
\end{tabular}


The figures in the product plan presented in Table 2 are exemplary. As stated, managers and planning specialists must have different approach to each product item by applying a different marketing and investment policy.

\section{CONCLUSIONS}

In conclusion, the following should be emphasized:

1. The proposed conceptual model of ranking of the product portfolios under the "contribution - profit - price" matrices system enables managers to make important strategic decisions for marketing and investment support for product groups and individual products.

2. The new matrix model "Contribution to growth", based on the methodology of the Boston Consulting Group, enables effective connectivity between the two core components of the company's business plan: the product and the investment plans.

3. The new "Contribution to growth" metrics system generates four quadrants in the twodimensional space, in which the company's product portfolio is displaced in a radically different way compared to the classical matrix of the BCG. This overcomes one of the main weaknesses of the BCG, according to which the cash flow is influenced only by the relative market share and the market growth. The used metrics "contribution" reflects the impact of many other nonmarket factors, especially technology and innovation, which alter the direct costs of raw materials, fuels and energy, wages and social security, and so on.

4. In economies with the prevailing presence and role of small and medium-sized enterprises, it is difficult to handle market shares, albeit relative ones. An important additional advantage of the new metrics system is that it enables managers of these enterprises to use convenient and relatively simple tools to make strategic decisions.

5. The new metric model of the product plan allows for much more differentiated and convincing investment support for the development and enrichment of the product portfolio of companies. In this way, another significant weakness of the BCG's classic model is overcome - the lack of a link to the return on investment.

6. Each model in the two-dimensional space comprises a limited number of factors. In this respect, the matrix model proposed in this paper should be used as a general framework for the establishment of the company's product plan. In making strategic decisions, managers should also consider the impact of other factors, such as investment competition, total factor productivity, financial resources, etc.

\section{REFERENCES}

1. Konstantinova, Sn. Planning the activities of the company. Plovdiv: Public house KSI, 2017, pp. 41-42. ISBN 978-954-2942-26-9

2. https://www.bcg.com/

3. Barow, P. The best laid business plans: how to write them, how to pitch them. Sofia: Classic and style, 2002.

4. Kotler, F., D. Hessekiel and N. Lee. Good Works!: Marketing and Corporate Initiatives That Build a Better World...and the Bottom Line. Sofia: Ciela, 2014.

5. Schwab, K. The Fourth Industrial Revolution. Plovdiv: Publishing house Hermes, 2016.

6. Christoph, A. Network Management. Sofia: New Bulgarian University, 2015.

7. Shen, X., et al. Mathematical models for real-world production planning problems with sequence-dependent set-up costs. France, ROADEF, 2015. 